\title{
The Effect of Reduced Maternofetal Blood Flow on the Development of Fetal Pancreatic Acinar Cells and Enzymes
}

\author{
EMANUEL LEBENTHAL, ${ }^{(30)}$ MENACHEM NITZAN, ${ }^{(31)}$ BARBARA L. CHRZANOWSKI, ${ }^{(32)}$ \\ AND BRIDGET KRANTZ
}

\author{
Division of Gastroenterology and Nutrition, Department of Pediatrics, State University of New York, Children's \\ Hospital of Buffalo, Buffalo, New York, and National Institute of Child Health, and Human Development, National \\ Institute of Health, Bethesda, Maryland, USA
}

\section{Summary}

It has been noted that from days 18 to 22 (birth) during the second intrauterine period of morphogenesis of the rat pancreas the accumulation of enzymes increases dramatically. We studied the effect of altered maternofetal blood flow on the development of the rat pancreas during the critical second period. Our studies indicate that during pancreatic cytodifferentiation, reduction in maternofetal blood flow not only reduces the weight of the pancreas (68\% of control) and diminishes the total activities of enzymes but that the changes in specific activities of the enzymes do not appear to be coordinate. The specific activities of amylase decreased to 59,000 units from the control value of 103,000 units $(P<0.01)$ and lipase decreased to $\mathbf{4 0 0 0}$ units from a control value of 7350 units $(P<0.001)$. In contrast, the specific activities of trypsin (ogen), chymotrypsin (ogen) and (pro)-carboxypeptidase $A$ and $B$ are not changed.

These results suggest that reduction in maternofetal blood flow caused a selective decrease of fetal rat amylase and lipase during the third trimester of gestation.

\section{Speculation}

The last trimester of gestation in the rat is a critical period for the development of enzymes in the fetal pancreas. Restriction of maternofetal blood flow affects the normal development of fetal organs, as reflected in changes of tissue specific enzymes. As in other stress conditions, intrauterine growth retardation affects amylase and lipase more than pancreatic proteases.

The ability of the exocrine pancreas to function and to secrete enzymes is limited even in full-term infants (29). However, in the small-for-gestational age and premature infant, inadequate pancreatic function can seriously affect digestion and their nutritional status (14). The last trimester of intrauterine life is critical for the maturation of exocrine pancreatic function. Changes induced by intrauterine growth retardation (IUGR) adversely affect digestive capacity.

In developed countries, IUGR is often caused by impaired maternal circulatory supply to the placenta. In fetal rats, the pancreas develops in two distinct stages $(13,20,21,23,27)$. The primary transition is from embryonic endoderm to a protodifferentiated state, when the pancreatic tissue contains low enzyme levels. The second stage begins about the 14th day of gestation, with an increased rate of synthesis of pancreatic exocrine enzymes (13) and the accumulation of secretory granules in the acinar cells (20). In the embryonic rat pancreas, amylase activity can be detected by the 16th day of gestation. In full-term rats, the pancreatic enzymes range from $25 \%$ of adult levels for trypsinogen to 15 to $20 \%$ for chymotrypsinogen, amylase, and lipase (25).
Our studies were designed to assess several aspects of exocrine pancreatic changes induced by IUGR in the last trimester including: pancreatic weight, cell number, protein content, and the specific and total activities of pancreatic enzymes.

\section{MATERIALS AND METHODS}

\section{ANIMALS AND SURGICAL PROCEDURES}

The experiment involved 20 pregnant Sprague-Dawley rats and 168 fetuses with accurately timed gestation (within $12 \mathrm{hr}$ ). The animals were caged individually and given free access to Purina laboratory pellets and tap water until surgery. Experimental intrauterine growth retardation was induced in 14 pregnant rats by a procedure devised by Wigglesworth (28). On the 18th day of gestation, a lower midline laparotomy was performed under anesthesia. The uterus was exposed, and the uterine artery supplying one uterine horn was ligated with two silk ligatures; the artery of the opposite uterine horn was untouched. After surgery, the incision was immediately closed with silk sutures. On the 22 nd day of gestation, the fetuses were delivered by cesarean section. The growth-retarded fetuses were identified by the suture on the arterial blood supply. The number of live fetuses in the ligated horn was 55, ranging from three to seven in each horn; in the opposite uterine horn, there were 59 , ranging from four to seven in each horn. After each fetus was weighed, its pancreas was removed from surrounding tissue, lightly blotted, weighed, and promptly frozen. Six additional pregnant Sprague-Dawley rats were used to determine the normal changes in the pancreas during the third trimester of intrauterine life. Their fetuses, delivered by cesarean section on days 17 to 21 of gestation, numbered from 8 to 11 at each delivery point.

\section{SAMPLE PREPARATION}

Each pancreas was homogenized in ice-cold saline $(1 \mathrm{mg} / 50$ $\mu l)$ with a Potter-Elvehjem homogenizer and a teflon pestle. Although enzyme activity was determined from fresh homogenate whenever possible the storage of homogenate at $-20^{\circ} \mathrm{C}$ resulted in little loss of enzyme activity after one thawing.

\section{BIOCHEMICAL ANALYSIS}

To activate the pancreatic proenzymes, a trace amount of enterokinase was added to the homogenate and allowed to incubate before the determination of enzyme activities. Trypsin (EC 3.4.4.4) activity was measured from the hydrolysis of $p$-nitroaniline from the substrate benzoyl-DL-arginine-p-nitroaniline at p.H. 8.2 and $25^{\circ} \mathrm{C}(5,18)$. Units were expressed as nmoles of benzoyl-DLarginine-p-nitroaniline hydrolyzed per min per $g$ of protein. Chymotrypsin (EC 3.4.4.5) was determined from the rate of hydrolysis 
on $N$-benzoyl-pL-tyrosine ethyl acetate ester as measured by the change in absorbance at $256 \mathrm{~nm}$ with time (12). Units were micromoles of substrate hydrolyzed per min per $\mathrm{g}$ of protein. $\alpha$ Amylase (EC 3.2.1.1) was determined from the colored product formed by the reduction of 3,5-dinitrosalicylic acid by maltose liberated per min per $\mathrm{g}$ of protein (25). Lipase (EC 3.1.1.3) activity was determined by the potentiometric titration (at a constant $\mathrm{pH}$ 8) of ionized fatty acids liberated from a triglyceride (olive oil) emulsion with $0.05 \mathrm{~N} \mathrm{NaOH} \mathrm{(8).} \mathrm{Units} \mathrm{were} \mathrm{expressed} \mathrm{as} \mathrm{micro-}$ moles of $\mathrm{NaOH}$ per min per $\mathrm{g}$ of protein. Carboxypeptidase $A$ (EC 3.4.2.1) was determined by the rate of increase in absorbance at $254 \mathrm{~nm}$ from the hydrolysis of hippuryl-L-phenylalanine at $25^{\circ} \mathrm{C}$ (7). The determination of carboxypeptidase B (EC 3.4.2.2) involved using hippuryl-L-arginine as the substrate (6). Activities were expressed as micromoles of substrate hydrolyzed per min per $g$ of protein. DNA was determined from the reaction with a diphenylamine chromogenic reagent after precipitation with cadmium (II) salts (10). Total proteins were derived from Sutherland's adaptation of the Lowry method using a Folin phenol reagent ( 15 , 26).

\section{STATISTICS}

The results are expressed as mean \pm S.D. Data from controls and malnourished fetuses from each of the 14 mothers were averaged and then subjected to a paired $t$ test. Because siblings were used as the control group, biologic variations between the two groups were minimized.

\section{RESULTS}

\section{THE EFFECT OF INTRAUTERINE GROWTH RETARDATION ON PANCREATIC GROWTH}

Ligation of the uterine arterial blood supply effectively reduced the blood supply and caloric intake of the rat fetuses and produced animals smaller than controls. Specifically, body weight of IUGR animals was $67 \%$ of the normal or control animals (Fig. 1). The difference in weight of the pancreas $(68 \%)$ was the same between the two groups of rats (Fig. 1), indicating a positive correlation between the reductions in body weight and the decrease in pancreatic size.

DNA concentrations in pancreatic tissue from both IUGR animals and controls did not differ statistically whether the results were expressed per gm of protein or per gm of tissue (Fig. 1). The similarity in DNA content between the two groups suggested that both control and IUGR animals had the same number of pancreatic cells per unit weight. The decrease in total DNA content (Fig. 1) between groups simply resulted from a reduction in the weight or size of the pancreas. Because the total DNA reflects the total number of cells, a reduction in $30 \%$ of the total DNA in the
IUGR fetuses suggested a decrease in the number of cells in this group of animals compared to the control siblings.

\section{INTRAUTERINE DEVELOPMENT OF PANCREATIC ENZYMES DURING NORMAL THIRD TRIMESTER}

Fetuses were delivered by cesarean section on days 17 to 21 of gestation. Amylase activity at days 20 and 21 was considerably higher than at full-term birth (22 days), having risen rapidly from near zero at 19 days of gestation (Fig. 2). During the same period of development, trypsin increased to a level slightly higher than the level at birth; lipase gradually approached $100 \%$ and chymotrypsin stayed at about 40 to $60 \%$ of the activity in the pancreas at 22 days of gestation.

These levels represent enzyme activities in pancreatic tissue at specific gestational ages; they are not necessarily the activities secreted by the pancreas.

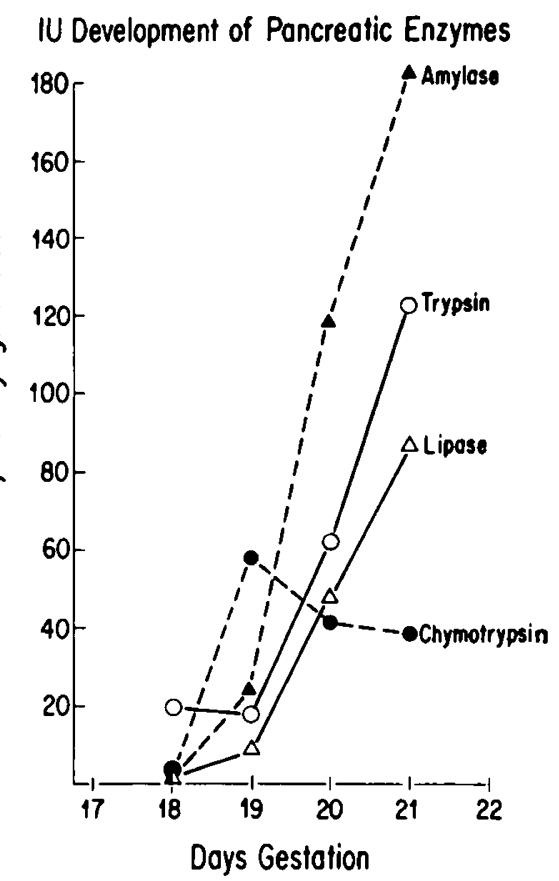

Fig. 2. Amylase $(\Delta)$, lipase $(\Delta)$, trypsin $(O)$, and chymotrypsin $(\Theta)$ content in normal fetal pancreas of rats 18 to 22 days of gestation. Points, mean of the enzyme activities from 8 to 11 fetuses. For clarity of presentation, no S.D. is depicted. Enzyme activities are expressed as percentage of the level of the newborn rat (22 days of gestation)
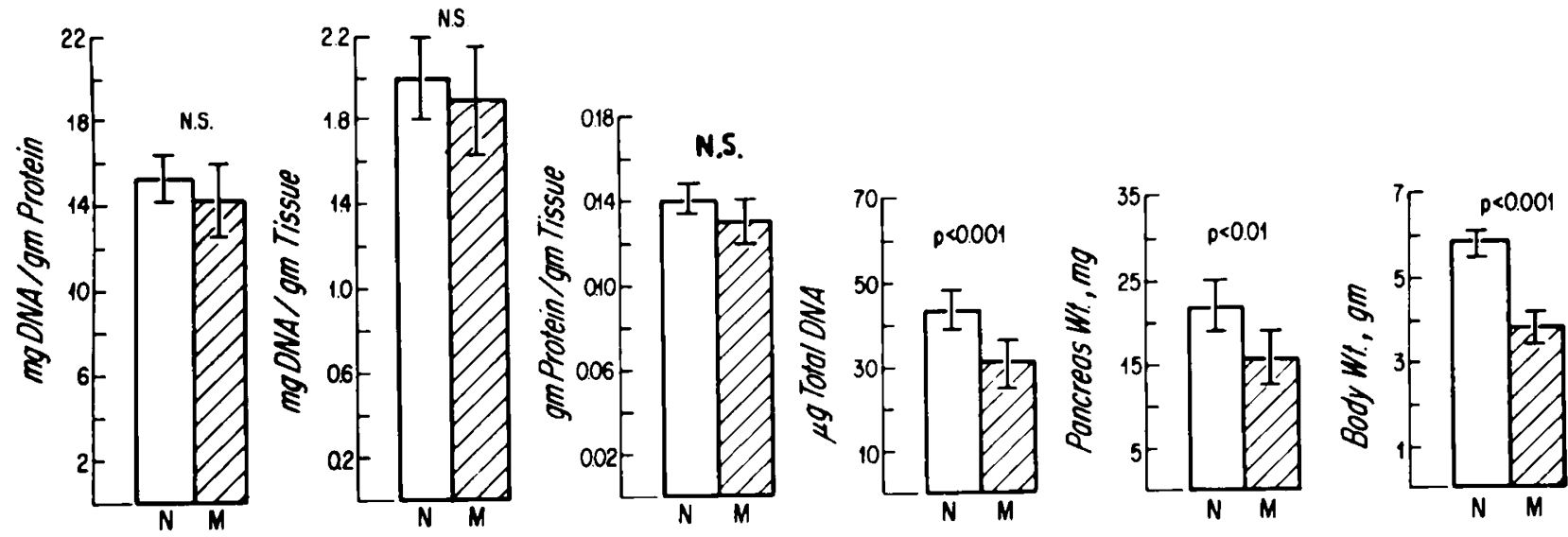

Fig. I. Comparison of DNA, protein content, and pancreatic and body weight of 59 normal newborn rats $(N)$ and 55 intrauterine growth retarded $(M)$. The bar height represents the mean value \pm 1 S.D. The statistical significance is illustrated on top of the bars. 
THE EFFECT OF INTRAUTERINE GROWTH RETARDATION ON THE ZYMOGEN PANCREATIC ENZYMES

The effect of IUGR on pancreatic zymogens, expressed as units per $g$ protein, were compared to those from normal fetuses. The specific activities (units $/ \mathrm{g}$ protein) of lipase $(P<0.001)$ and amylase $(P<0.01)$ were significantly lower in IUGR fetuses compared to normals (Fig. 3). The specific activities of trypsin, chymotrypsin and carboxypeptidase $A$ and $B$ in IUGR fetuses were not statistically different from their paired normal fetuses (Fig. 4).

\section{DISCUSSION}

The development of the exocrine pancreas exhibits a regular biological pattern. In fetal rats, the accumulation of enzymes, plotted logarithmically against time, follows a sigmoid curve. Each enzyme has a different curve, but an inflection point occurs between 16 and 18 days gestation $(23,24)$ for all of them.

When actinomycin D or 6-bromodeoxyuridine was added to the culture medium of fetal pancreas cells, the period of rapid accumulation of enzyme was preceded by a period of nucleic acid synthesis. Thus, it seems that the 13th to 15th days of gestation are critical in relation to this synthesis (24).

The rapid accumulation of enzymes about day 18 of gestation (Fig. 2) was in accord with previously published data $(23,24)$. At this time, a reduction in maternofetal blood flow led to a decrease in pancreatic weight commensurate with the reduced body weight (Fig. 1). Because the DNA content per $g$ tissue was unchanged (Fig. 1), it appears that the low weight of the pancreas was due to reduction in the number of pancreatic cells; nevertheless, changes in cell size cannot be completely ruled out. Similar changes in other organs have been shown using the Wigglesworth model (11, $17,22)$.

The total activity of all enzymes was low in the IUGR rats.

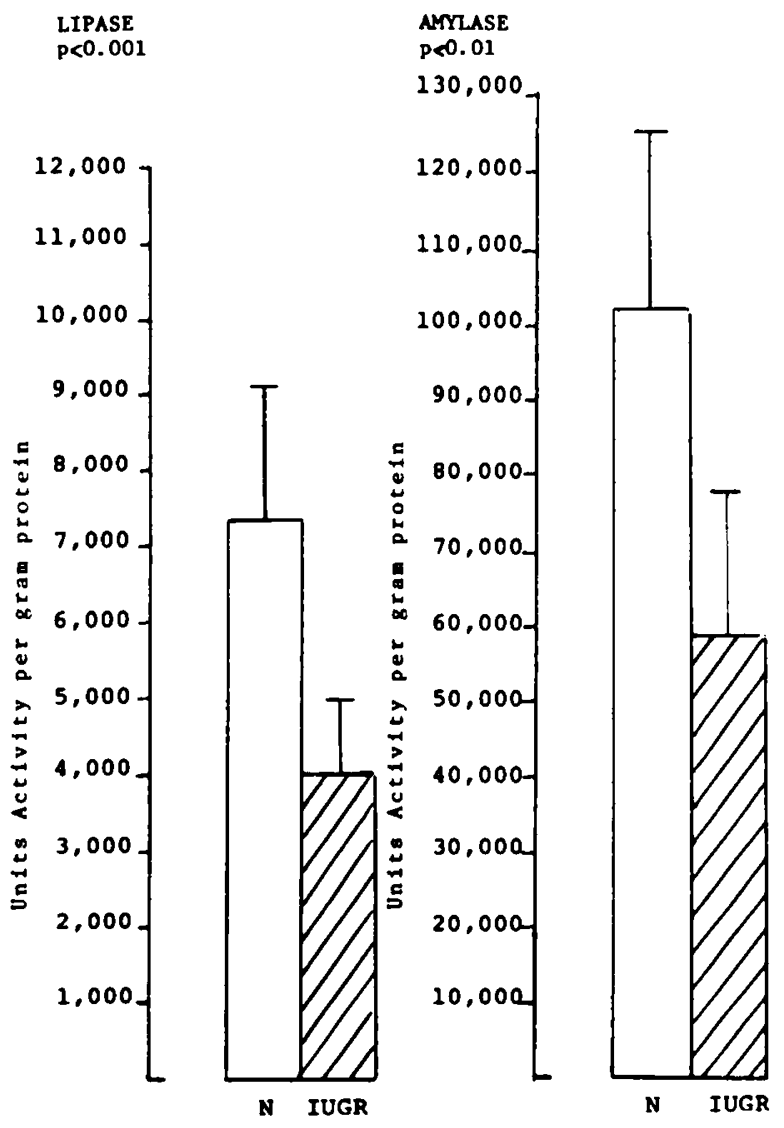

Fig. 3. Comparison of lipase and amylase activities expressed per $g$ protein in 59 normal $(N)$ and 55 intrauterine growth-retarded (IUGR) newborn rats. The bar height represents the mean value \pm S.D.

\section{Effect of IUGR on Pancreatic Peptidoses}
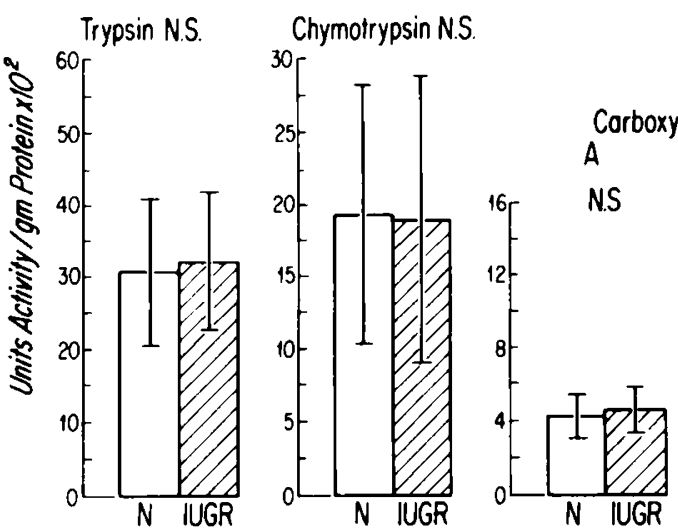

Corboxypeptidase

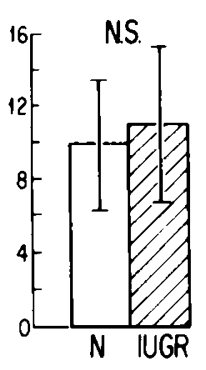

$N=$ Normal

IUGR I Introuterine Growth Retordation

Fig. 4. Comparison of trypsin, chymotrypsin, and carboxypeptidase $A$ and $\mathrm{B}$ activities expressed per $\mathrm{g}$ protein in 59 normal $(N)$ and 55 intrauterine growth retarded (IUGR) newborn rats. The bar height represents the mean value \pm S.D.

However, the various enzymes were affected differently; the specific activities of amylase and lipase were reduced, whereas the specific activities of the proteases, specifically trypsin, chymotrypsin, and carboxypeptidases A and B, remained unchanged. This corroborates previous observations $(1,2,9)$ that amylase and lipase were more sensitive to stress than the proteases. In suckling mice, infection with reovirus resulted in a decrease in amylase and lipase and an increase in proteases (1). Furthermore, when mice were given injections with leukemic cells, amylase, and lipase activities decreased more than those of trypsinogen and chymotrypsinogen (2). In rats, postnatal malnutrition affected lipase and amylase more than chymotrypsinogen and procarboxypeptidase (9), suggesting that the synthesis of different enzymes or proenzymes is under different biochemical control.

The concept of nonparallel development of enzymes is not new. Marchaim and Kulka (16) noted a differential increase in various hydrolases during the last wk of embryonic life in chicks. Deschodt-Lanckman et al. (4) found that the levels of various enzymes did not change in a constant proportion during the prenatal period. The mechanisms controlling the biosynthesis of various enzymes are apparently not identical. Perhaps they are induced by different stimuli.

The exact mechanisms leading to pancreatic dysfunction in malnourished states (either pre- or postnatally) remain obscure. The developing pancreas depends on the supply of amino acids (19). It is also known that the rate of $\mathrm{Na}^{+}$-dependent amino acid transport in the rat pancreas rises sharply several days before birth and falls immediately after birth (3). Nitzan et al. (17) demonstrated a large reduction in maternofetal transfer of $\alpha$-aminoisobutyric acid when intrauterine blood flow was reduced. Thus, it is possible that the reductions in the number of pancreatic cells and in enzyme activities are related to a diminished supply of amino acids during a critical stage of selective protein synthesis.

In conclusion, the third trimester (after 16th day of gestation) in the embryonic development of the rat is a critical stage in the biosynthesis of pancreatic enzymes. Restriction of maternofetal blood flow during this period interfered with the normal emergence of pancreatic hydrolases and caused a reduction in total enzyme activities. Furthermore, the decrease in some enzymes, i.e., lipase and amylase, was greater than the decrease in total proteins in the same organ. The reductions in other enzymes, i.e. proteases, were proportional to the decrease in the total proteins.

\section{REFERENCES AND NOTES}

1. Branski, D., Lebenthal. E., Faden, H., Hatch, T. F., and Krasner, J.: Reovirus type 3 infection in suckling mouse: the effects on pancreatic structure and enzyme content. Pediatr. Res., 14: 8 (1980). 
2. Branski, D., Lebenthal, E., Hatch. F. F., Krasner, J., Fisher, J. E., and Freeman, A. I.: The pancreas in leukemic mice and the effects of methotrexate. Dig. Dis. Sci., 24: 867 (1979).

3. Cheneval, J. P., and Johnstone, R. M.: Transport of amino acids in rat pancreas during development. Biochim. Biophys. Acta., 345: 17 (1974).

4. Deschodt-Lanckman, M., Robberecht, P., Camus, J.. Baya, C., and Christophe J.: Hormonal and dietary adaptation of rat pancreatic hydrolases before and after weaning. Am. J. Physiol., 226: 39 (1974).

5. Erlanger, B. F., Kokowsky, N., and Cohen, W.: The preparation and properties of two new chromogenic substrates of trypsin. Arch. Biochem. Biophys., 95 : 271 (1961).

6. Folk, J. E., Piez, K. A., Carroll, W. R., and Gladner, J. A.: Carboxypeptidase B. IV. Purification and characteristics of the porcine enzyme. J. Biol. Chem., 235 2272 ( 1970)

7. Folk. J. E., and Schirmen, E. W.: The porcine pancreatic carboxypeptidase A system. I. Three forms of the active enzymes. J. Biol. Chem., 238: 3884 (1963).

8. Hadorn, B.: Assessment of pancreatic function. In: C. M. Anderson, V. Burke: Gastroenterology p. 663 (Blackwell Scientific Publications, Oxford, 1975).

9. Hatch, T. F., Lebenthal, E., Krasner, J., and Branski, D.: The effect of postnata malnutrition on pancreatic zymogen in the rat. Am. J. Clin. Nutr.. 32: 1224 (1979).

10. Hatcher, D. W., and Goldstein, G.: Improved methods for determination of RNA and DNA. Anal. Biochem.. 31: 42 (1969)

1I. Hohenauer, L., and Oh. W.: Body composition in experimental intrauterine growth retardation in the rat. J. Nutr., 99: 23 (1969).

12. Hummel, B. C. W.: Modified spectrophotometric determination of chymotrypsin, trypsin, and thrombin. Can. J. Biochem. Physiol., 37: 1393 (1959).

13. Kemp, J. D., Walther, B. T., and Rutter, W. J.: Protein synthesis during the secondary developmental transition of the embryonic rat pancreas. J. Biol. Chem., 247: 3941 (1972).

14. Lebenthal, E.: Pancreatic function and disease in infancy and childhood. Adv. Pediatr., 25: 223 (1978)

15. Lowry, O. H., Rosebrough, N. J., Farr, A. L., and Randall, R. J.: Protein measurement with the Folin phenol reagent. J. Biol. Chem. 193: 265 (1951).

16. Marchaim, U., and Kulka. R. G.: The non-parallel increase of amylase, chymotrypsinogen and procarboxypeptidase in the developing chick pancreas. Biochim. Biophys. Acta. 146: 553 (1967)

17. Nitzan, M., Orloff, S., and Schulman, J. D.: Placental transfer of analogs of glucose and amino acids in experimental intrauterine growth retardation. Pediatr. Res. 13: 100 (1979).

18. Nordstrom, C.. and Dahlquist. A.: Rat enterokinase: the effect of ions and the localization in the intestine. Biochim. Biophys. Acta, 242: 209 (1971).

19. Parsa, I., March, W. H., and Fitzgerald, P. J.: Pancreas acinar cell differentiation. Exp. Cell Res., 73: 49 (1972).

20. Pictet, R. L., Clark, W. R., Williams, R. H. and Rutter, W. J.: An Ultrastructural analysis of the developing embryonic pancreas. Dev. Biol., 29: 436 (1972)

21. Pictet, R. L., and Rutter, W. J.: Development of the embryonic endocrine pancreas. In: D. F. Steiner, N. Freinkel: Handbook of Physiology, Vol. I. Section 7, p. 25 (Williams \& Wilkins Co., Baltimore, MD, 1972).

22. Pollak, A., Susa, J. B., Stonestreet, B. S., Schwartz, R., and Oh, W.: Phosphoenolpyruvate carboxykinase in experimental intrauterine growth retardation in rats. Pediatr. Res., 12: 175 (1979).

23. Rutter, W. J., Kemp, J. D., Bradshaw, W. S., Clark, W. R., Ronzio, R. A., and Sander, T. G.: Regulation of specific protein synthesis in cytodifferentiation. J. Cell Physiol. 72 (Suppl. 1): I (1968).

24. Sanders, T. G., and Rutter, W. J.: The development regulation of amylolytic enzymes in the embryonic rat pancreas. J. Biol. Chem., 249: 3500 (1974)

25. Searcy, R. L., Hayaski, S., and Berk, T. E.: A new microsaccharogenic method for serum amylase determinations. Tech. Bull. Regist. Med. Tech., 36: 252. (1966).

26. Sutherland, E. W., Cor, C. F., Haynes, R., and Olsen N. S.: Purification of the hyperglycemic-glycogenolytic factor from insulin and from gastric mucosa. J. Biol. Chem., 180: 825 (1949).

27. Walther, B. T., Pictet, R. L., David, J. D., and Rutter, W. J.: On the mechanism of 5-bromodeoxyuridine inhibition of exocrine pancreas differentiation. J. Biol. Chem., 249: 1953 (1974).

28. Wiggelsworth, J. C.: Experimental growth retardation in the fetal rat. J. Pathol. Bacteriol., 88: 1 (1964).

29. Zoppi, G., Andreotti, G., Pajno-Ferrara, F., Njai. D. M., and Gaburro, D.: Exocrine pancreas function in premature and full term neonates. Pediatr. Res., 6: 880 (1972)

30. This paper was presented in part at the joint Meeting ESPGAN and N. Am Soc. Pediatr. Gastroenternol, Paris, May, 1978: American Gastroenterology Aseociation Meeting, Las Vegas, Nevada, May, 1978; XI International Congress on Nutrition, Rio de Janerio, September, 1978; and the American Pancreatic Association Meeting, Chicago IL, November, 1978.

31. The present address of Dr. Menachem Nitzan is: Department of Pediatrics, Beilinson Medical Center, Petah Tikva and Sackler School of Medicine, TelAviv University, Tel-Aviv, Israel.

32. The present address of Dr. Barbara L. Chrzanowski is: National Research Institute of Mother and Child, 17 Kapraka Street, Warsaw, Poland.

33. The authors would like to thank Dr. Joseph D. Schulman from the National Institute of Health for his help in the execution and revision of this manuscript. We would like to thank Ok Kim and Stephen Brooks for their technical assistance and Mary Lou Stein for her secretarial assistance.

34. Requests for reprints should be addressed to: Emanuel Lebenthal, M.D., Division of Gastroenterology, Children's Hospital, 219 Bryant Street, Buffalo, NY 14222 (USA).

35. Received for publication September 17, 1979.

36. Accepted for publication March 20, 1980. 